\title{
Competition modifies the response of organisms to toxic disturbance
}

\author{
Emma L. Johnston ${ }^{1,2, *}$, Michael J. Keough ${ }^{1}$ \\ ${ }^{1}$ Department of Zoology, University of Melbourne, Victoria 3010, Australia
}

${ }^{2}$ Present address: Centre for Marine and Coastal Studies, University of New South Wales, Sydney, New South Wales 2052, Australia

\begin{abstract}
Transient pollution events have the potential to cause both direct and indirect effects on exposed assemblages, but the test designs used in the majority of toxicity studies have precluded an examination of potentially important indirect effects. Field experiments conducted in marine epifaunal assemblages have revealed that pulse chemical disturbances from copper decrease the densities of large solitary ascidians while increasing the densities of serpulid polychaetes. Field manipulative experiments were carried out to test whether the positive effects of transient pollution events represent the response of serpulids to the release from competition for space (an indirect effect of the toxicant) or a direct positive response to the putative toxicant. Three species of serpulid polychaetes (Ficopomatus enigmaticus, Hydroides sp., and Pileolaria pseudomilitaris) responded positively to pulse copper exposures in the presence of competition, but did not display any density response to pulse copper exposures in the absence of competition for space from other recruits. Pomatoceros taeniata displayed no response to copper exposure in the presence of competition, but was dramatically reduced in density in the absence of competition for space. This was the only species deemed sensitive to the frequency and intensity of pollution disturbance employed. There was no indication of a direct positive effect of the toxicant on any serpulid, confirming the hypothesis that positive responses of serpulids to copper exposure in the whole assemblage are an indirect effect of the toxicant mediated through competition for space. Our results show that the interaction between a pollution disturbance and competition for a limiting resource can modify the response of organisms to a toxicant. Such results could not be predicted from conventional laboratory-based toxicity tests and they suggest that small-scale ecotoxicological field tests are a useful tool in predicting the impacts of pollution events in complex systems.
\end{abstract}

KEY WORDS: Pulse disturbance · Competition · Indirect effects · Sessile invertebrates · Pollution · Copper $\cdot$ Polychaetes $\cdot$ Ascidians

Resale or republication not permitted without written consent of the publisher

\section{INTRODUCTION}

Pulse pollution events, like short-term natural disturbances, have the potential to directly reduce the densities of organisms within an assemblage. If the affected species are ecologically important-good competitors, habitat-forming species or effective predators - there may be cascades of effects, resulting in increases or decreases in species not directly affected by the pollutant (DeAngelis 1996). Field monitoring studies of pollution have identified both positive and negative effects of toxicants on particular species (Rygg 1985). A positive response to pollutants may indicate that a direct benefit to a species has occurred (e.g. if a pollu- tant is also a potential food source such as sewage effluent). For highly toxic substances it is considered more likely that the positive response of a species reflects an indirect benefit from the freeing-up of resources as competitors are removed by direct toxicity (Rygg 1985). Some populations may be influenced both by the direct negative toxic affect of the pollution event and by indirect positive effects that result from perturbations in neighbouring populations.

Field experiments in the marine environment have regularly identified indirect effects that are the result of physical and biological disturbances (e.g. Connell 1961a, Paine 1966, Dayton 1971, Schmitt 1987, Petraitis 1990). A recent synthesis of experimental 
manipulations in the rocky intertidal zone found that indirect effects could account for 24 to $61 \%$ of change in community structure (Menge 1995). Despite the widespread recognition of their existence (Kareiva 1994) and estimation of their importance (Menge 1995), indirect effects have rarely been tested for explicitly in any ecosystem (for an exception and a suggested approach see Wootton 1992 and 1994).

Conventional toxicity studies are usually conducted on a single species or population and they lack the ability to predict the indirect effects of toxicants on organisms mediated through some other resource (Kimball \& Levin 1985, Luoma 1995, DeAngelis 1996). In freshwater ecotoxicology, researchers have found micro- and mesocosm-based tests useful for the identification of the indirect effects of toxicants (for a brief review see DeAngelis 1996). These studies may have limited relevance, however, if confining communities to a mesocosm has the effect of limiting recruitment, predation or other biological interactions that are important in open systems (Luoma 1995, Carpenter 1996). In such cases, manipulative field experiments are a useful tool to investigate the potential for toxicants to cause indirect effects (Kareiva et al. 1996).

Previous experiments had indicated that space was a limiting resource in the assemblage of hard-substrate, sessile, marine invertebrates and had identified solitary ascidians as dominant competitors (Johnston \& Webb 2000, Johnston \& Keough 2002, Johnston et al. 2002, E. L. Johnston \& M. J. Keough unpubl.). Under pulse pollution regimes, abundances of large solitary and colonial ascidians were decreased while those of serpulids increased. More specifically, copper pulse disturbances every $4 \mathrm{wk}$ increased the abundance of 3 serpulid species, Hydroides sp., Ficopomatus enigmaticus, and the spirorbid Pileolaria pseudomilitaris, but reduced the density of a 4 th serpulid, Pomatoceros taeniata (Johnston \& Keough 2002, E. L. Johnston \& M. J. Keough unpubl.).

We hypothesised that the positive response of serpulid polychaetes to copper was an indirect effect of the toxicant mediated through competition for space. Moreover, we suggested that the majority of serpulids (Hydroides sp., Ficopomatus enigmaticus and Pileolaria pseudomilitaris) were insensitive to copper pulses occurring at such an intensity and frequency. An alternative hypothesis is that the settlement of serpulid polychaetes is enhanced by low concentrations of the toxicant (hormesis). Indeed, newly settled serpulids were also found in dramatically increased abundances $(\approx 85 \%)$ in copper-dosed assemblages (Johnston \& Keough 2002, E. L. Johnston \& M. J. Keough unpubl.). Serpulids did not exploit secondary surfaces (e.g. ascidian tests) readily, however, and we interpreted their increased densities as a positive response to the availability of primary settlement space on copperdosed plates. We assumed that new settlers had arrived after the final disturbance event.

The aim of this study was to test the predictions derived from the previous experiments concerning interspecific competitive effects and their interactions with direct pollution impacts. Our predictions concerned species-specific responses of adults and newly settled serpulid populations exposed to copper pollution in the absence of competition for space from other organisms. Through a direct test we aimed to identify the positive responses of serpulids as either the result of hormesis, or the result of an indirect effect of the toxicant.

We predicted that, following competitive release, the indirect positive effect of copper pulses on densities of Hydroides sp., Ficopomatus enigmaticus and Pileolaria pseudomilitaris would be removed, leading to no difference or a reversed (i.e. negative) effect of copper pulses on these serpulids. Despite dramatic structural changes in assemblages, we had previously observed no consistent effect of copper on the densities of Pomatoceros taeniata. For this serpulid, we suggested that density increases due to indirect effects of the toxicant had been similar in magnitude to density decreases resulting from direct toxic effects. Following competitive release, therefore, we predicted that this serpulid would no longer gain an indirect benefit and would be reduced in abundance by exposure to copper pulses.

To achieve our aim we employed a field dosing technique in 2 experiments run concurrently at a site in Port Philip Bay. One experiment replicated a subset of treatments from previous years examining the impacts of the frequency and intensity of pulse copper disturbances on developing assemblages of sessile marine invertebrates. The aim of this experiment was to confirm the temporal generality of patterns upon which our specific predictions had been based. Our specific predictions were tested with a field pulse pollution experiment in which settlement plates were maintained free of all organisms besides serpulid polychaetes. Thus, serpulids were subject to frequentpulse copper pollution disturbances but could recruit and grow in the absence of competition for space from other organisms.

\section{MATERIALS AND METHODS}

Study site. Research was carried out at Breakwater Pier, one of 3 sites in temperate Port Philip Bay, Victoria, Australia, where we have previously conducted pulse pollution experiments (Johnston \& Keough 2000, 2002, Johnston \& Webb 2000). Breakwater Pier extends $300 \mathrm{~m}$ offshore and is protected by a rocky 
breakwater on its southern side. Public access is restricted at this site.

The toxicant. In all experiments $\mathrm{AR}$ grade $\mathrm{CuSO}_{4}$ (copper II sulphate anhydrous) was used as the toxicant. Copper is a common constituent of many anthropogenic waste products released into aquatic systems, as well as a commonly used anti-foulant in estuaries and bays (Luoma \& Phillips 1988, Paulson et al. 1989, Stephenson \& Leonard 1994, Pitt 1995, Apte \& Day 1998, Stauber et al. 2000). Copper is highly toxic to marine invertebrates, interfering with metabolic pathways and binding to enzymes and gill structures (Hall et al. 1998).

Toxicant dosing. In all experiments copper-spiked plaster blocks were used to deliver the toxicant dose as described in Johnston \& Keough (2002). Two copper strengths were used in the frequency versus intensity experiment. The low concentration plaster blocks each contained $1.6 \mathrm{~g}$ of $\mathrm{CuSO}_{4}$ while the high concentration plaster blocks each contained $3.2 \mathrm{~g}$ of $\mathrm{CuSO}_{4}$. All settlement plates were immersed on site for a period of $1 \mathrm{wk}$ to allow microbial film development before attachment of the first plaster block. All plates received either a copper-impregnated or control plaster block every $4 \mathrm{wk}$ for the duration of the experiments (16 wk). Plates were maintained in a pool of local seawater while plaster blocks were replaced.

Experimental design. Two 4 mo disturbance experiments were initiated on the same day in December 1999 and were situated adjacent to each other (2 m separation). Both were suspended from Breakwater Pier at a depth of $3.5 \mathrm{~m}$ below the low water mark. Settlement plates were attached to the underside of backing plates to minimise available light and sedimentation. For a description and illustration of plaster block attachment and settlement plates experimental set up, see Johnston \& Keough (2002). Previous studies were used to estimate the required treatment replication in this study. No more than 8 small settlement plates were attached to any 1 backing plate, with the distance between the edge of neighbouring plates no less than $10 \mathrm{~cm}$. To avoid possible bias by differential recruitment onto areas of backing plates, positions were divided into 3 categories: corner, centre or edge. Treatments were assigned randomly within each category. Four backing plates were used in the frequency and intensity experiment and 2 backing plates in the space experiment. All levels of each treatment occur on each backing plate.

Frequency and intensity experiment. This experiment was designed to replicate a sub- set of experimental treatments that have been run at several sites and over several years examining disturbance frequency and intensity interactions (Johnston \& Webb 2000, Johnston \& Keough 2002, Johnston et al. 2002, E.L. Johnston \& M.J. Keough unpubl.). It also allowed a general comparison of polychaete recruitment with the second space experiment (below). There were 5 treatments: an undosed control (plaster blocks only); low concentration (1.6 g) copper pulse every $4 \mathrm{wk}$ (hereafter referred to in the format $4 \mathrm{wk} 1.6$, for this and other periods and concentrations); high concentration copper pulse every $4 \mathrm{wk}$ (4wk3.2); high concentration copper pulse every $8 \mathrm{wk}$ (8wk3.2); and high concentration copper pulse every 8 wk, with staggered timing of the pulses $(8 \mathrm{wk} 3.2$ staggered). In the staggered pulses, treatment plates received their first copper pulse 4 wk into the experiment. Six replicate settlement plates were randomly assigned to each treatment.

Space experiment. This experiment consisted of 2 treatments: a control (plaster blocks only), and a high concentration copper pulse every $4 \mathrm{wk}(4 \mathrm{wk} 3.2)$. There were 8 replicate plates of each treatment spread over 2 backing plates. Each treatment occupied 1 corner, 1 centre and 2 side positions on each backing plate. All recruits, except for serpulid polychaetes, were removed from settlement plates at $2 \mathrm{wk}$ intervals using fine forceps. Plates were maintained in a collapsible pool of local water during this process. Water was replaced constantly to maintain local water quality conditions. Backing plates were maintained free of all recruits with the use of a paint scraper. For a schematic representation of both experimental designs, see Fig. 1.

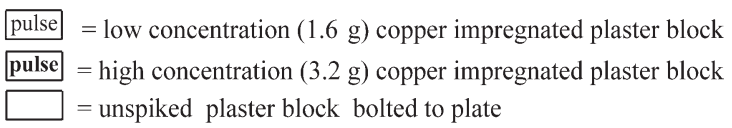

Space Experiment (Only serpulid polychaetes)

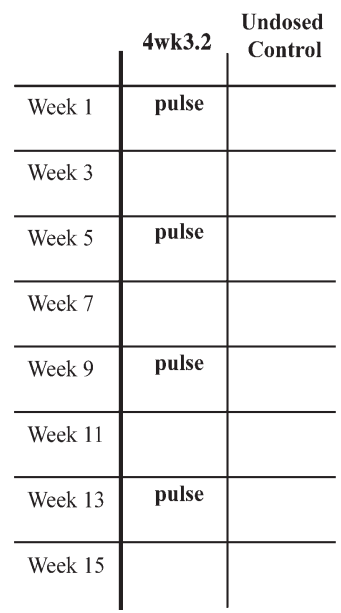

Frequency and Intensity Experiment (All recruits)

\begin{tabular}{|c|c|c|c|c|c|}
\hline & 4wk1.6 & $4 w k 3.2$ & $8 w k 3.2$ & $\begin{array}{l}\text { 8wk3.2- } \\
\text { staggered }\end{array}$ & $\begin{array}{l}\text { Undosed } \\
\text { Control }\end{array}$ \\
\hline Week 1 & pulse & pulse & pulse & & \\
\hline \multicolumn{6}{|l|}{ Week 3} \\
\hline Week 5 & pulse & pulse & & pulse & \\
\hline \multicolumn{6}{|l|}{ Week 7} \\
\hline Week 9 & pulse & pulse & pulse & & \\
\hline \multicolumn{6}{|l|}{ Week 11} \\
\hline Week 13 & pulse & pulse & & pulse & \\
\hline Week 15 & & & & & \\
\hline
\end{tabular}

Fig. 1. Schematic representation of experimental design. See text for details 
Census. At the conclusion of each experiment, settlement plates were transported in seawater to the laboratory and placed in a continuous-flow seawater system until they were examined. Plates were examined under a binocular dissecting microscope and the position of serpulid recruits in every second square, and large ascidians $\left(>1 \mathrm{~cm}^{2}\right)$ within each $1 \mathrm{~cm}^{2}$ of a $10 \times$ $10 \mathrm{~cm}$ grid, were noted (this excluded areas within $0.5 \mathrm{~cm}$ of the plate perimeter and the area that was at any time covered by the $4 \mathrm{~cm}$ diameter plaster block). The spirorbid Pileolaria pseudomilitaris was counted in 3 size classes according to the width of the tube opening: small (0 to $0.2 \mathrm{~mm})$, medium (0.2 to $0.5 \mathrm{~mm}$ ) and large $(>0.5 \mathrm{~mm})$. For all other serpulids it was not possible to consistently discriminate among species for new settlers $(<0.1 \mathrm{~mm}$ width of tube opening), so they were censused as a distinct group (i.e. newly settled serpulids). For this group, and for the small serpulids ( 0.1 to $0.5 \mathrm{~mm}$ width of tube opening), the presence of a live organism was usually obvious through the thin calcareous plate. All medium (0.5 to $1 \mathrm{~mm}$ ) and large serpulid tubes $(>1 \mathrm{~mm}$ ) were checked for the presence of a live serpulid, usually by breaking the tube open with forceps. Only live serpulids were analysed. Plates were examined without knowledge of the treatment to which they had been subjected. In the frequency and intensity experiment, the percent cover of all large solitary and colonial ascidians $\left(>1 \mathrm{~cm}^{2}\right.$ ) on primary space was estimated using the total number of $\mathrm{cm}^{2}$ they covered, divided by the area of the plate. Free space was then back-calculated as the area of the plate surface not covered by a solitary or colonial ascidian.

Analysis. Frequency and intensity experiment: Initially the analysis was run on all ascidians and serpulids. Most serpulids were counted in several size classes. If size classes responded in the same way to treatments (e.g. Pileolaria pseudomilitaris), then size class data were pooled and the results of pooled analy-

Table 1. Analysis of the effect of copper pulses on the density or proportional cover of Ascidian and serpulid taxa in Breakwater Pier frequency vs intensity experiment. Probabilities, error terms and mean squares are shown for the main test (all treatments). Probabilities and mean squares are presented for the planned comparisons which were tested against the error term from the main test. See text for details of pulse treatments. Significant differences $(p<0.05)$ are highlighted in bold

\begin{tabular}{|c|c|c|c|c|c|c|c|}
\hline \multirow[t]{2}{*}{ Taxonomic group } & \multicolumn{3}{|c|}{$\begin{array}{l}\text { Main test } \\
\mathrm{df}=4,25\end{array}$} & & \multicolumn{2}{|c|}{ Planned comparisons $\mathrm{df}=1,25$} & Timing \\
\hline & MS & $\mathrm{MS}_{\text {error }}$ & $\mathrm{p}$ & $\mathrm{p}$ & $\mathrm{p}$ & $\mathrm{p}$ & $\mathrm{p}$ \\
\hline \multicolumn{8}{|l|}{ Ascidians } \\
\hline Pyura stolonifera & 0.046 & 0.006 & 0.000 & 0.000 & 0.149 & 0.793 & 0.037 \\
\hline Ascidiella aspersa & 0.016 & 0.005 & 0.026 & 0.002 & 0.176 & 0.662 & 0.749 \\
\hline Ciona intestinalis & 0.015 & 0.009 & 0.209 & 0.036 & 0.125 & 0.724 & 0.315 \\
\hline Styela clava & 0.007 & 0.004 & 0.165 & 0.076 & 0.773 & 0.076 & 0.398 \\
\hline Large red sp. & 0.014 & 0.005 & 0.037 & 0.003 & 0.040 & 0.370 & 0.886 \\
\hline All large & 0.069 & 0.007 & 0.000 & 0.000 & 0.014 & 0.930 & 0.074 \\
\hline \multicolumn{8}{|l|}{ Proportional cover } \\
\hline All solitary ascidians & 0.285 & 0.023 & 0.000 & 0.000 & 0.002 & 0.844 & 0.079 \\
\hline All colonial ascidians & 0.007 & 0.011 & 0.618 & 0.291 & 0.865 & 0.245 & 0.516 \\
\hline Free space & 0.244 & 0.016 & 0.000 & 0.000 & 0.000 & 0.306 & 0.083 \\
\hline \multicolumn{8}{|l|}{ Serpulids } \\
\hline \multicolumn{8}{|l|}{ Pomatoceros taeniata } \\
\hline Large live & 0.111 & 0.032 & 0.022 & 0.029 & 0.022 & 0.111 & 0.022 \\
\hline Medium live & 0.064 & 0.014 & 0.007 & 0.005 & 0.580 & 0.695 & 0.061 \\
\hline Small live & 0.036 & 0.013 & 0.047 & 0.006 & 0.448 & 0.259 & 0.251 \\
\hline \multicolumn{8}{|l|}{ Hydroides sp. } \\
\hline Large live & 0.031 & 0.014 & 0.098 & 0.030 & 0.378 & 0.195 & 0.344 \\
\hline Medium live & 0.097 & 0.023 & 0.010 & 0.018 & 0.752 & 0.226 & 0.007 \\
\hline Small live & 0.030 & 0.014 & 0.101 & 0.010 & 0.100 & 0.649 & 0.712 \\
\hline \multicolumn{8}{|c|}{ Ficopomatus enigmaticus } \\
\hline Large live & 0.022 & 0.007 & 0.036 & 0.008 & 0.026 & 0.318 & 0.139 \\
\hline Medium live & 0.087 & 0.013 & 0.001 & 0.000 & 0.001 & 0.050 & 0.310 \\
\hline Small live & 0.107 & 0.013 & 0.000 & 0.000 & 0.000 & 0.877 & 0.361 \\
\hline \multicolumn{8}{|c|}{ Pileolaria pseudomilitaris } \\
\hline All live & 0.046 & 0.015 & 0.033 & 0.012 & 0.523 & 0.175 & 0.048 \\
\hline \multicolumn{8}{|l|}{ Newly settled serpulids } \\
\hline Live & 0.645 & 0.047 & 0.000 & 0.000 & 0.000 & 0.535 & 0.247 \\
\hline
\end{tabular}


ses presented. Examination of the plots of residual errors for each taxon indicated that the analysis should be conducted on the square-root transformed data. Proportional covers were arcsin square-root transformed. Analysis was conducted according to the following steps: (1) A 1-way ANOVA was conducted on the transformed density of each taxon, with copper treatment as the categorical factor. The mean square error from this test provided the error term for all subsequent planned comparisons. (2) A planned comparison of the control treatment against the appropriate treatment (4wk3.2) was conducted for comparison with the space experiment. (3) Three simple planned comparisons were conducted to test for the effect of copper pulse intensity (4wk1.6 vs $4 \mathrm{wk} 3.2$ ), frequency versus intensity (4wk1.6 vs $8 w k 3.2)$ and the effects of staggered timing of pulses $(8 \mathrm{wk} 3.2$ vs $8 \mathrm{wk} 3.2-$ staggered).

The number of planned comparisons (4) did not exceed the degrees of freedom in the main test, so no adjustment of significance level was made (Quinn \& Keough 2002). Significant results were found for almost all taxa so power analyses were not conducted. Backing plates represented an experimental unit of convenience and we have detected no interaction between backing plate and treatment in previous studies. We therefore did not include backing plate as a blocking factor in the analysis of either experiment.

Space experiment: ANOVA was conducted on the transformed density with copper treatment as the categorical factor. Where there was a non-significant result, power calculations were conducted using PiFace (Lenth 1997). The power of the test to detect a $50 \%$ difference from the control was calculated. Effect sizes of a $50 \%$ difference from control have been reported in previous copper pulse recruitment experiments, and in response to a range of other experimental treatments at Breakwater Pier (Keough \& Raimondi 1995, 1996, Johnston \& Keough 2000). We considered a power $>80 \%$ to be reasonable for this test and we have little confidence in the results of tests with power lower than this. For the purposes of clarity and brevity, the results outlined for the space experiment are for tests that had power $>80 \%$. For taxonomic groups that had power $<80 \%$, we present the results in graphs and tables only.

\section{RESULTS}

\section{Frequency and intensity experiment}

Solitary ascidians (see Table 1, Fig. 2)

In contrast to previous years, Ciona intestinalis was a minor constituent of the assemblage, with approximately 4 large recruits per control plate in this study. $C$. intestinalis densities were reduced $(\approx 75 \%)$ by exposure to frequent high concentration copper pulses. There was no effect of copper pulses on $C$. intestinalis densities from pulse exposures every $8 \mathrm{wk}$, and no effect was detected of staggered timing at this fre-

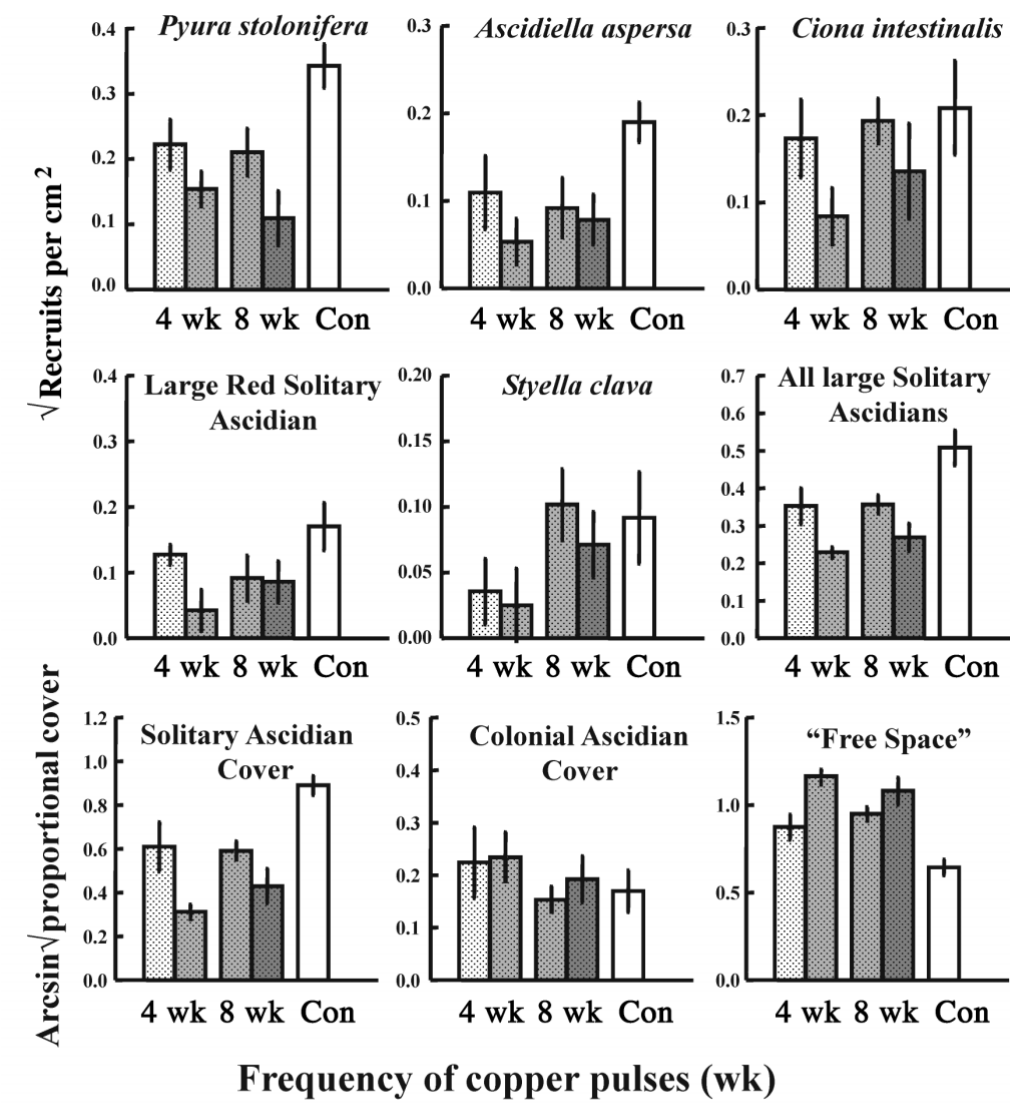

Fig. 2. Density and proportional cover of ascidian taxa in 4 mo frequency versus intensity experiment. The frequency of copper pulses is indicated on the $x$-axis: treatments are undosed control (Con), copper pulse every 4 wk and copper pulse every $8 \mathrm{wk}$. Light grey bars indicate a low concentration copper pulse $\left(1.6 \mathrm{~g} \mathrm{CuSO}_{4}\right)$, while darker grey indicates a high concentration copper pulse $\left(3.2 \mathrm{~g} \mathrm{CuSO}_{4}\right)$. Bars in dark grey indicate the timing of the high concentration copper pulses was staggered by $4 \mathrm{wk}$. Bars show the square root of the mean density of recruits $\left(\mathrm{cm}^{-2}\right)$ or the arcsin square roottransformed proportional cover. Error bars are $\pm 1.0 \mathrm{SE}$ 
quency. Other common ascidians in control assemblages were: Pyura stolonifera (ca. 13 per control plate), Ascidiella aspersa (ca. 4 per plate), Styela clava (ca. 1 per plate), and a large red solitary sp. 1 (ca. 3 per plate). All of the solitary ascidians, except S. clava, were reduced in densities on plates exposed to copper pulses every $4 \mathrm{wk}$ (4wk3.2) compared to the control. The overall density of solitary ascidians was reduced by $75 \%$ in this treatment. The low-concentration pulse treatment (4wk1.6) had less impact on solitary ascidian densities, similar to the effect of the less frequent high-concentration pulse treatment (8wk3.2).

Percentage cover (Table 1, Fig. 2) of colonial ascidians (botryllinid and didemnid colonies > $1 \mathrm{~cm}^{2}$ ) was minor compared with the cover of solitary ascidians, and only ever contributed a maximum of $8 \%$ to any plate. There was no effect of copper pulse treatments on the percentage cover of colonial ascidians. The percentage cover of large solitary ascidians displayed the same pattern as the abundance of large solitary ascidians, and this was the opposite for free space. Thus, the amount of free space decreased according to the following order of treatments: $4 \mathrm{wk} 3.2>4 \mathrm{wk} 1.6=$ 8wk3.2 = 8wk3.2-staggered $>$ control.

\section{Serpulids}

Pomatoceros taeniata (Table 1, Fig. 3) was the most abundant serpulid in this experiment, and large recruits were reduced by high concentration pulse exposures every 4 or $8 \mathrm{wk}$. Medium and small recruits, however, had higher densities on dosed plates. Neither low concentration pulses (4wk1.6), nor the staggered timing of high concentration pulses (8wk3.2-staggered) reduced densities of large $P$. taeniata relative to the control.

Large, medium and small Hydroides sp. densities (Table 1, Fig. 3) were highest in treatments exposed to high concentration pulses every $4 \mathrm{wk}$ (4wk3.2). There were lower densities of medium-sized recruits on plates exposed to the staggered pulse exposure compared with the standard exposure regime (i.e. 8wk3.2 vs 8wk3.2-staggered); however, there were no such differences for large and small recruits. There were no differences caused by the intensity of the pulse (i.e. $4 \mathrm{wk} 1.6$ vs 4wk3.2).

Large, medium and small Ficopomatus enigmaticus densities (Table 1, Fig. 3) were highest in treatments exposed to high concentration pulses every $4 \mathrm{wk}$ (4wk3.2). The staggered timing of pulses caused no differences between the impact of copper pulse exposures delivered at $8 \mathrm{wk}$ intervals (8wk3.2 vs 8wk3.2-staggered). For all size classes, the low concentration pulse treatment (4wk1.6) had far lower densities (similar to that of the controls) than the high concentration copper pulse treatment $(4 \mathrm{wk} 3.2)$. There were higher densities of medium sized serpulids on plates exposed to a high concentration pulses every

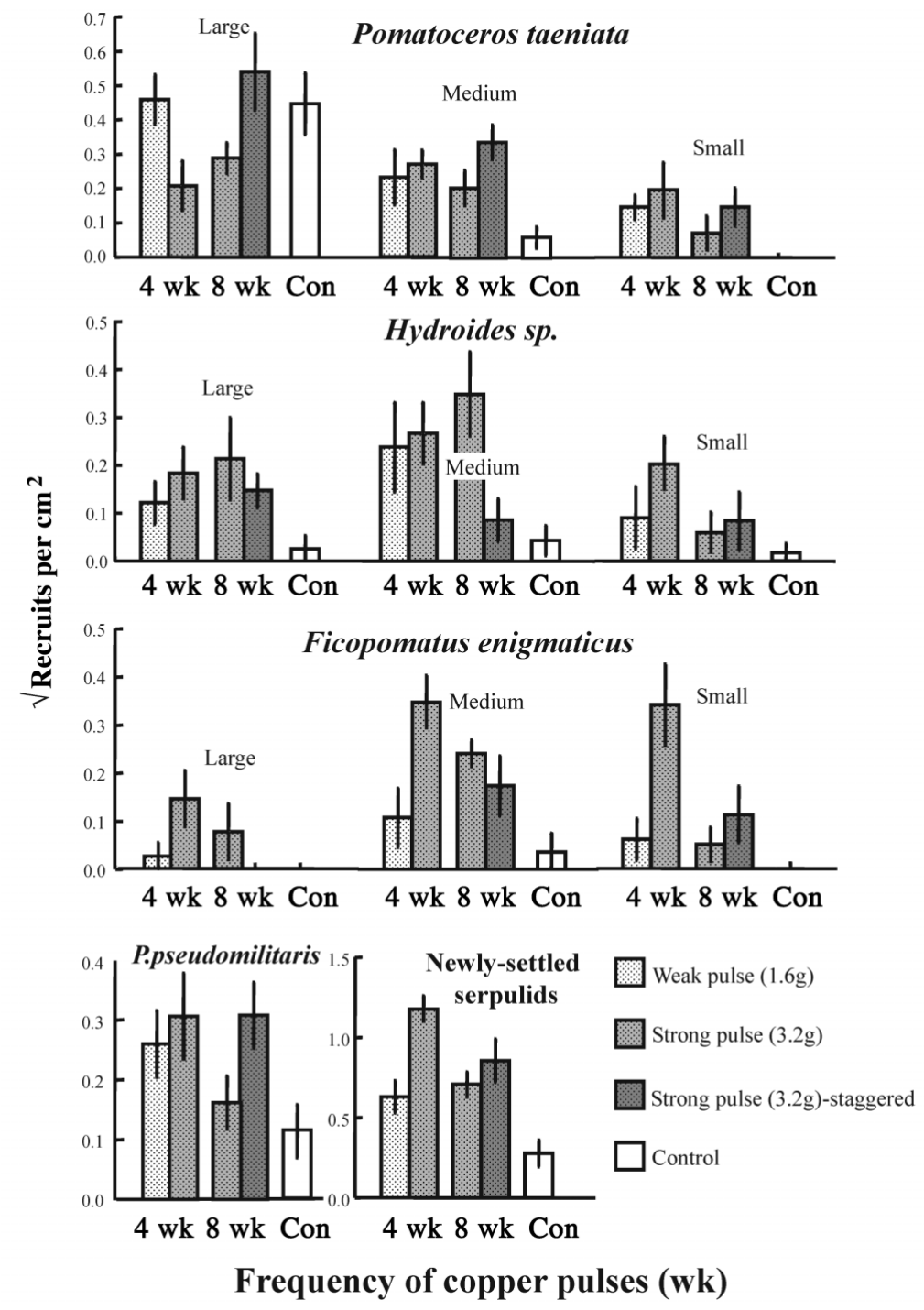

Fig. 3. Density of serpulid taxa in 4 mo frequency versus intensity experiment. The frequency of copper pulses is indicated on the $x$-axis: treatments are undosed control (Con), copper pulse every 4 wk and copper pulse every $8 \mathrm{wk}$. Light grey bars indicate a low concentration copper pulse $\left(1.6 \mathrm{~g} \mathrm{CuSO}_{4}\right)$, while darker grey indicates a high concentration copper pulse $\left(3.2 \mathrm{~g} \mathrm{CuSO}_{4}\right)$. Bars in dark grey indicate the timing of the high concentration copper pulses was staggered by $4 \mathrm{wk}$. Bars show the square root of the mean density of recruits $\left(\mathrm{cm}^{-2}\right)$. Error bars are $\pm 1.0 \mathrm{SE}$ 
$8 \mathrm{wk}(8 \mathrm{wk} 3.2)$ than a low concentration pulse every $4 \mathrm{wk}(4 \mathrm{wk} 1.6)$.

Large medium and small Pileolaria pseudomilitaris recruits (a spirorbid; Table 1, Fig. 3) reacted in the same way to copper pulses for this taxon so size classes were pooled to increase the power of the test. $P$. pseudomilitaris densities were highest on copperdosed plates, although plates dosed every $8 \mathrm{wk}$ were similar to controls while plates dosed with staggered timing every $8 \mathrm{wk}$ (8wk3.2-staggered) had higher densities.

Newly settled serpulid densities (Table 1, Fig. 3) were generally higher on copper-dosed treatments, but the effect was most marked when high concentration copper pulses were delivered every $4 \mathrm{wk}$ ( $4 \mathrm{wk} 3.2$ treatment had densities 16 times that of control treatment).

\section{Space experiment}

Results outlined below are for tests that had power $>80 \%$. For taxonomic groups that had power $<80 \%$ (i.e. small Pomatoceros taeniata, small Hydroides sp., large and small Ficopomatus enigmaticus, medium Pileolaria pseudomilitaris and dead Hydroides sp.), we present the results in graphs and tables only (see Table 2, Fig. 4).

Of the serpulids (Table 2, Fig. 4), Pomatoceros taeniata was by far the most abundant in this experiment, and large and medium recruits were reduced by approximately $75 \%$ by copper pulses delivered every $4 \mathrm{wk}$. There was no effect of copper pulses on large or medium Hydroides sp. There was no effect of copper pulses on medium Ficopomatus enigmaticus and there was no effect of copper pulses on large Pileolaria pseudomilitaris. New recruits of $P$. pseudomilitaris were abundant and copper pulses increased the densities of this group by approximately $75 \%$. Copper pulses increased the densities of newly settled serpulids to almost double that of control levels.

\section{DISCUSSION}

\section{Frequency versus intensity experiment}

The consistency of results across years at this site increases the temporal generality of our findings and confirms the relevance of the predictions outlined in the 'Introduction'. Although recruitment has varied between seasons, the effects of copper pulses on species and functional groups have been consistent. For example, over 3 yr at Breakwater Pier, the importance of Ciona intestinalis to the developing assemblages has varied from 44 large individuals per settlement plate $\left(100 \mathrm{~cm}^{2}\right)$ accompanied by little else in 1997/1998 (Johnston \& Keough 2002), to 10 per plate in 1998/1999 (E. L. Johnston \& M. J. Keough unpubl.), and down to a low of 4 per plate in this study (1999/2000). Each year, a regime of pulsed copper pollution exposures every $4 \mathrm{wk}$ has reduced densities of this large solitary ascidian by between 70 and $80 \%$. Moreover, as $C$. intestinalis has become less abundant each year, it has been replaced by a variety of other solitary ascidians (e.g. Pyura stolonifera, and Ascidiella aspersa), many of which have been similarly affected by copper pulses (see this study and E. L. Johnston \& M. J. Keough unpubl.).

The abundances of various serpulid polychaetes have also differed between years, but again the impacts of copper exposures have been consistent. For 3 consecutive years at this site, copper pulses have increased the densities of 3 species of serpulid, Hydroides sp., Ficopomatus enigmaticus, and the spirorbid Pileolaria pseudomilitaris. In addition, copper pulses have increased the densities of newly settled serpulids (Johnston \& Keough 2002, E. L. Johnston \& M. J. Keough unpubl., this study). In previous years Pomatoceros taeniata had shown no response to copper pulses delivered every 4 wk (Johnston \& Keough 2002, E. L. Johnston \& M. J. Keough unpubl.), or a decrease in densities at a higher frequency of disturbances (e.g.

Table 2. Analysis of the effect of copper pulses on the density of serpulid taxa in Breakwater Pier Space Experiment. Probabilities, error terms and mean squares are shown for the main test (all treatments). Power values (in \% terms) for the ANOVA are included. Significant differences $(p<0.05)$ and power values $>80 \%$ for non-significant treatments are highlighted in bold

\begin{tabular}{|c|c|c|c|c|}
\hline \multirow{2}{*}{$\begin{array}{l}\text { Taxonomic } \\
\text { group }\end{array}$} & \multicolumn{3}{|c|}{ ANOVA df $=1,14$} & \multirow{2}{*}{$\begin{array}{c}\text { Powel } \\
\%\end{array}$} \\
\hline & MS & $\mathrm{MS}_{\text {error }}$ & $\mathrm{p}$ & \\
\hline \multicolumn{5}{|c|}{ Pomatoceros taeniata } \\
\hline Large live & 1.9138 & 0.0539 & $<0.000$ & \\
\hline Medium live & 0.3696 & 0.0163 & $<0.000$ & \\
\hline Small live & 0.0022 & 0.0198 & 0.746 & 25 \\
\hline \multicolumn{5}{|l|}{ Hydroides sp. } \\
\hline Large live & 0.0459 & 0.0147 & 0.099 & 87 \\
\hline Medium live & 0.0051 & 0.0134 & 0.547 & 93 \\
\hline Small live & 0.0755 & 0.0274 & 0.119 & 9 \\
\hline \multicolumn{5}{|c|}{ Ficopomatus enigmaticus } \\
\hline Large live & 0.0103 & 0.0117 & 0.363 & 41 \\
\hline Medium live & 0.0095 & 0.0081 & 0.297 & 87 \\
\hline Small live & 0.0543 & 0.0167 & 0.092 & 12 \\
\hline \multicolumn{5}{|c|}{ Pileolaria pseudomilitaris } \\
\hline Large live & 0.0045 & 0.0099 & 0.511 & 91 \\
\hline Medium live & 0.0001 & 0.0174 & 0.944 & 67 \\
\hline Small live & 0.2710 & 0.0204 & 0.003 & \\
\hline \multicolumn{5}{|c|}{ Newly settled serpulids } \\
\hline Live & 0.5716 & 0.0741 & 0.015 & \\
\hline
\end{tabular}




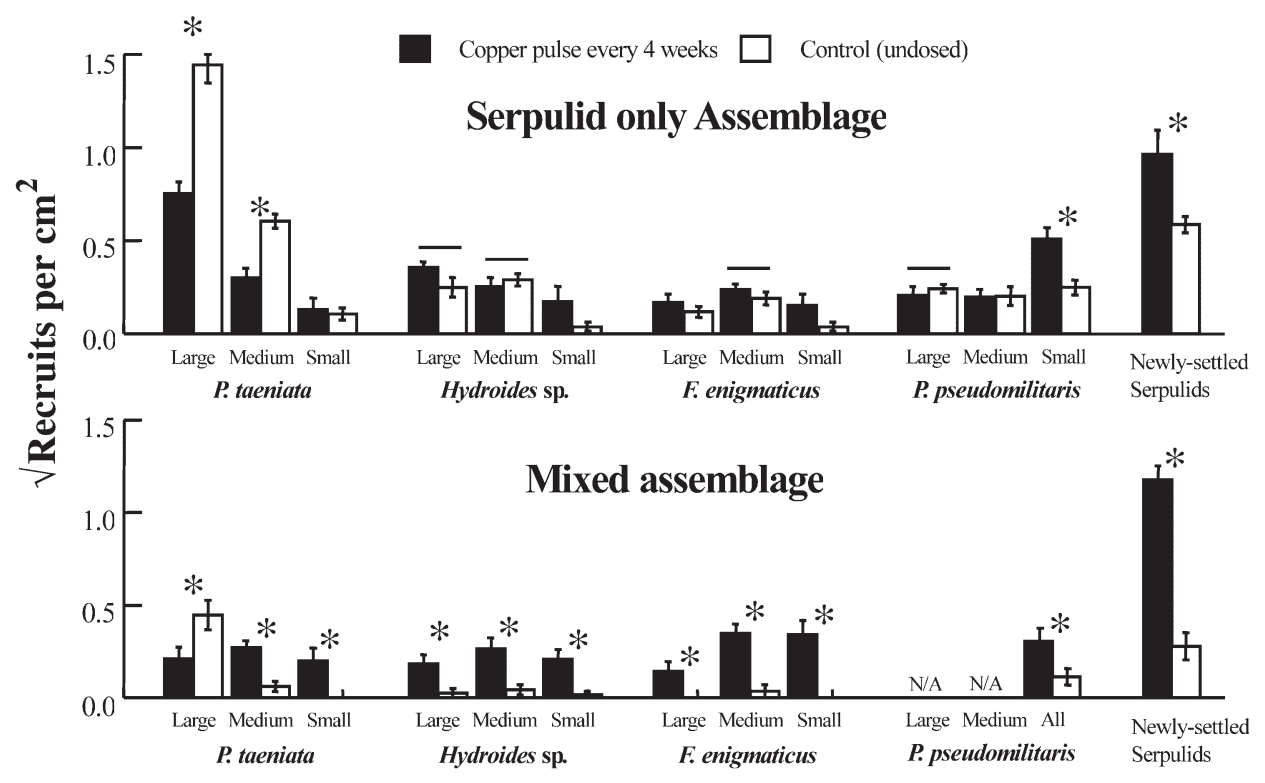

Fig. 4. Density of serpulid taxa in 4 mo space experiment (serpulid only assemblage) and selected treatments extracted for ease of comparison from the frequency versus intensity experiment (mixed assemblage). Treatments are undosed control (unshaded bar) and copper pulse every $4 \mathrm{wk}$ (black bar). Bars show the square root-transformed mean density of recruits $\left(\mathrm{cm}^{-2}\right)$. Error bars are $\pm 1.0 \mathrm{SE}$. Asterisks indicate a significant difference between treatments. Lines indicate that there was no significant different between treatments, and the power of the test was $>80 \%$

delivered every 2 wk, E. L. Johnston \& M. J. Keough unpubl.). In this study, the serpulid displayed a decrease in large recruits but an increase in the densities of medium and small recruits. This resulted in no overall response to the copper pulses. The general response of serpulids and ascidians to copper pulses has therefore been consistent not only in 3 consecutive years at one site, but also among sites within Port Phillip Bay (Johnston \& Keough 2002, E. L. Johnston \& M. J. Keough unpubl.), and at an additional site in subtropical Hong Kong (Johnston et al. 2002).

There were no differences between the impact of a low concentration pulse delivered every 4 wk and a high concentration pulse delivered every $8 \mathrm{wk}$. There were, however, many significant differences between the impacts of low- and high-concentration pulses delivered at the same frequency (every $4 \mathrm{wk}$ ). The higher concentration pulse generally had a greater effect on organism densities, whether that be positive or negative. In situ measurements of the pollution event created by this technique at Breakwater Pier show that a $2 \mathrm{~d}$ pulse of approximately $8 \mathrm{~g} \mathrm{fl}^{-1}$ is created for the low-concentration pulse and $25 \mathrm{~g} \mathrm{\mu l}^{-1}$ for the high-concentration pulse (Johnston 2001). Background copper concentrations at this site are less than $1 \mathrm{~g} \mathrm{pl}^{-1}$ (Johnston 2001). Within the disturbance range tested in this study, the minimisation of impacts could only be achieved through an overall reduction in the amount of toxicant released rather than any manipulations of the frequency or intensity of disturbance.

\section{Frequency versus space experiments}

The 2 experiments in this study were run simultaneously and adjacent to each other (within $2 \mathrm{~m}$ and at the same depth) but not as an integrated experiment. Although environmental conditions between them are unlikely to differ, shared treatments do have the potential to be spatially confounded, so no formal comparisons were conducted. The consistency of response to copper pulses outlined above does confirm the relevance of a comparison of the response of serpulids to copper-pulse pollution events, in the presence and absence of competition for space from other recruits. To assist our comparison, the results from this study, previous studies and our predictions are summarised in Table 3, and the results from Space experiment are graphically presented along side the relevant treatments (control and $4 \mathrm{wk} 3.2$ ) from the frequency versus intensity experiment (Fig. 4).

\section{Species-specific results}

If we compare control assemblages between the 2 experiments we see that there were higher densities of every serpulid taxon in the space experiment than in the presence of other organisms (frequency versus intensity experiment). As predicted, populations of the 3 serpulid species (Hydroides sp. Ficopomatus enigmaticus and Pileolaria pseudomilitaris), which were 
Table 3. Summary of the response of serpulids and solitary ascidians to copper pulses occurring every 4 wk in the presence of competition for space (whole assemblage) and the absence of this competition from other recruits (serpulid only assemblage). Predictions were based on the results of previous studies. $+=$ density increase, $-=$ density decrease, $0=$ no effect on density

\begin{tabular}{|lccccc|}
\hline \multirow{2}{*}{ Taxon } & \multicolumn{2}{c}{ Whole assemblage } & \multicolumn{3}{c|}{ Serpulid only assemblage } \\
& Previous studies & This study & Predictions & This study & Predictions met \\
\hline Pomatoceros taeniata & 0 & 0 & - & - & Yes \\
Hydroides sp. & + & + & 0 & 0 & Yes \\
Ficopomatus enigmaticus & + & + & 0 & 0 & Yes \\
Pileolaria pseudomilitaris & + & + & 0 & + & Yes \\
Newly settled serpulids & + & + & Recruits removed & Recruits removed & N/A \\
Solitary ascidians & - & - & & & \\
\hline
\end{tabular}

found in increased densities on copper-dosed plates in the presence of competition for space, displayed no response to copper pulses in the absence of this competition. Also, as predicted, populations of large Pomatoceros taeniata, the most abundant serpulid in the assemblage, and an organism that has previously gained little indirect advantage from copper pulses, was reduced by exposure to copper pulses in the absence of competition for space from other recruits.

Our initial interpretation thus appears to be correct. The positive effect of copper pulses on serpulid recruits is in fact a response to the release from competition for space from their superior competitors. There was also high power to detect the effects of copper on serpulids in the absence of competition for space from other recruits and we are confident that Hydroides sp. and Ficopomatus enigmaticus are insensitive to copper pulse exposures that occur every $4 \mathrm{wk}$. The serpulid Pomatoceros taeniata does, however, appear to be directly sensitive to copper pulses, with densities reduced by more than $70 \%$ in the absence of competition for space. Thus it would appear that within a complex assemblage, the direct toxic effects of copper on this serpulid, are of similar magnitude, but opposite direction, to the indirect effects of a release from competition for space. Only in the absence of an indirect benefit did the toxic effect of copper on this species become obvious.

\section{Newly settled serpulids}

In contrast to the species-specific responses of adult serpulid recruits, the response of newly settled serpulids (which were too young to identify to specieslevel) did not conform to our predictions. In the absence of competition for space from other recruits, we expected that the indirect benefit from increased primary settlement space would be removed, and the newly settled serpulids would not have increased densities on plates exposed to copper pulses. In fact, there was still a significant increase in the densities of newly settled serpulids on copper-dosed plates. Early laboratory-based ecotoxicology tests identified a positive response of some organisms to low levels of toxicants (hormesis). This resulted in the induction of settlement of several invertebrate larvae, although survival beyond metamorphosis was usually reduced (Lynch 1961, Wisely 1963). Our short-term pollution experiments have either failed to detect induction/hormesis or have detected direct reductions in serpulid recruitment caused by copper pulses in the field (Johnston \& Keough 2000, Johnston 2001). In this study, the recruits in our newly settled size classes were almost certainly less than 4 wk old and were likely, therefore, to have recruited after the final copper pulse was delivered to the assemblages. We therefore consider hormesis to be an unlikely explanation for the increased densities of new serpulid recruits on copper-dosed plates.

Field experiments suggest that serpulids may respond to cues that indicate bare space (e.g. new biofilms, Unabia \& Hadfield 1999) and settle preferentially onto bare substrate (Dean \& Hurd 1980, Dean 1981, Keough \& Raimondi 1995). Although there was still primary settlement space available on plates in our space experiment, reduced larval recruitment can occur before all primary space is occupied (Raimondi 1990, Berlow \& Navarette 1997). It is likely that the high densities of large Pomatoceros taeniata on control plates $\left(>1 \mathrm{~cm}^{-2}\right)$ reduced the settlement of new recruits, and therefore in the final stages of this experiment, interference and/or pre-emptive competition was occurring within the serpulid-only assemblage. In order to test this explanation, fortnightly or monthly censuses of the plates would be required.

Space on which to live is often the most important limiting resource in marine hard-substratum environments (Connell 1961b, Dayton 1971, Paine 1974, Sutherland 1974, Osman 1977). Studies on hard-substrate sessile marine fauna have generally found serpulid polychaetes to be good colonizers but possibly the worst competitors for space. They are consistently 
overgrown or pushed out by colonial and solitary ascidians, sponges and encrusting bryozoans (Jackson 1977, Osman 1977, Sutherland \& Karlson 1977, Dean \& Hurd 1980, Russ 1980, Dean 1981, Kay \& Keough 1981, Greene et al. 1983, Keough 1984, Nandakumar et al. 1993, Unabia \& Hadfield 1999). Longer-term studies from coral reefs have also shown that good colonizers may be out-competed by later arrivals (Connell \& Slatyer 1977, Tanner et al. 1994). The trend is commensurate with the theoretical assumption underlying many models of community dynamics of a negative correlation between colonisation (or dispersal) and competitive abilities (Petraitis et al. 1989, Tilman 1990).

If a trade-off between competitive and dispersive abilities is found to be a general trait, it would imply that pulse pollution events might have the general effect of disadvantaging good competitors and giving an indirect advantage to good colonizers but poor competitors. Some have suggested that this might result in anthropogenic disturbances causing extinctions of good competitors regardless of the specific system involved (Tilman 1994). In our assemblage we did see a distinct disadvantage conferred on the good competitors by episodic pollution events. In an open system such as marine epifaunal assemblages, however, pulse anthropogenic disturbances are likely to cause only temporary and localised extinctions of species unless they occur on a scale large enough to affect all propagule sources.

Our experiments are limited in their spatial scale. This will prove to be a common problem of field ecotoxicology where it would be entirely self-defeating to manipulate disturbances on the scales at which we aim to predict their impact (Wiens \& Parker 1995). We do expect the impacts of pollution events to be scaledependent in a nontrivial way. For example, we would expect impacts of larger scale pollution events on species to differ depending on an organism's dispersal potential. In this case, larvae with a greater dispersal potential (e.g. longer larval lives - more time spent in the plankton) might be better able to recover at a site than poor dispersers. Repeated pulse disturbances should, therefore, advantage good dispersers. This trend can be examined in a non-manipulative manner by examining the spatial autocorrelation of organisms following a large-scale disturbance (see Reed et al. 2000).

\section{Conclusions}

Our results confirmed our predictions down to the level of individual species' responses. They show that an organism's response to pulse pollution events in the field will be an integration of direct toxicity and indirect effects of the toxicant. Organisms that are poor competitors but capable of settling, growing and reproducing in the interval between episodic pollution events will gain advantages. These studies show that the impact of short pulses of pollution can be discerned over and above the dynamic effects of factors that are acting on the assemblage such as inter- and intraspecific competition, and environmental fluctuations. The interaction between a pollution disturbance and competition for a limiting resource modifies the response of organisms to a toxicant. We were able to discern some toxicant effects that would be impossible to detect, and difficult to predict from the results of laboratory or mesocosm based toxicity tests. This work highlights the need to incorporate field experiments into the study of pollutants on ecosystems, and demonstrates that small-scale ecotoxicological field tests are a useful tool for predicting the impacts of pollution events in complex systems.

Acknowledgements. We are grateful to many people for assistance with fieldwork, but especially to S. P. Maresh, J. E. Johnston, E. Bone and D. Marshall. We thank R. Wilson of the Museum of Victoria for assistance with serpulid identifications. We thank the Port of Melbourne Authority for providing access to Breakwater Pier. We are indebted to L. Morris, J. Carey, and D. Marshall for their insightful comments on the original manuscript. E.L.J. was supported throughout this study by an Australian Government Postgraduate Award (APA).

\section{LITERATURE CITED}

Apte SC, Day GM (1998) Dissolved metal concentrations in the Torres Strait and Gulf of Papua. Mar Pollut Bull 36: 298-304

Berlow EL, Navarette SA (1997) Spatial and temporal variation in rocky intertidal community organisation: lessons from repeating field experiments. J Exp Mar Biol Ecol 214: 195-229

Carpenter SR (1996) Microcosm experiments have limited relevance for community and ecosystem ecology. Ecology 77 : $677-680$

Connell JH (1961a) Effects of competition, predation by Thais lapillus, and other factors on natural populations of the barnacle Balanus balanoides. Ecology 31:61-104

Connell JH (1961b) The influence of interspecific competition and other factors on the distribution of the barnacle Chthamalus stellatus. Ecology 42:710-723

Connell JH, Slatyer RO (1977) Mechanisms of succession in natural communities and their role in community stability and organisation. Am Nat 111:1119-1144

Dayton PK (1971) Competition, disturbance and community organisation: the provision and utilisation of space in a rocky intertidal community. Ecol Monogr 41:351-389

Dean T (1981) Structural aspects of sessile invertebrates as organizing forces in an estuarine fouling community. J Exp Mar Biol Ecol 53:163-180 
Dean T, Hurd L (1980) Development in an estuarine fouling community: the influence of early colonists on later arrivals. Oecologia 46:295-301

DeAngelis DL (1996) Indirect effects: concepts and approaches from ecological theory. In: Baird DJ, Maltby L, Greig-Smith P, Douben P (eds) ECOtoxicology: ecological dimensions. Chapman \& Hall, London, p 25-41

Greene CH, Schoener A, Corets E (1983) Succession on marine hard substrata: the adaptive significance of solitary and colonial strategies in temperate fouling communities. Mar Ecol Prog Ser 13:121-129

Hall LWJ, Scott MC, Killen WD (1998) Ecological risk assessment of copper and cadmium in surface waters of Chesapeake Bay watershed. Environ Toxicol Chem 17: 1172-1189

Jackson J (1977) Competition on marine hard substrata: the adaptive significance of solitary and colonial strategies. Am Nat 111:743-767

Johnston EL (2001) Effects of transient copper pollution events on the ecology of marine epifaunal assemblages. $\mathrm{PhD}$ thesis, University of Melbourne

Johnston EL, Keough MJ (2000) Field assessment of the effects of the timing and frequency of copper pulses on settlement of sessile marine invertebrates. Mar Biol 137: 1017-1029

Johnston EL, Keough MJ (2002) Direct and indirect effects of repeated pollution events on marine hard-substrate assemblages. Ecol Appl 12:1212-1228

Johnston EL, Webb JA (2000) Novel techniques for field assessment of copper toxicity on fouling assemblages. Biofouling 15:165-173

Johnston EL, Keough MJ, Qian PY (2002) Maintenance of species dominance through pulse disturbances to a sessile marine invertebrate assemblage in Port Shelter, Hong Kong. Mar Ecol Prog Ser 226:103-114

Kareiva P (1994) Higher order interactions as a foil to reductionist ecology. Ecology 75:1527-1528

Kareiva P, Stark J, Wennergren U (1996) Using demographic theory, community ecology and spatial models to illuminate ecotoxicology. In: Baird DJ, Maltby L, Greig-Smith P, Douben P (eds) ECOtoxicology: ecological dimensions. Chapman \& Hall, London, p 13-23

Kay AM, Keough MJ (1981) Occupation of patches in the epifaunal communities on pier pilings and the bivalve Pinna bicolor at Edithburgh, South Australia. Oecologia 48:123-130

Keough MJ (1984) Effects of patch size on the abundance of sessile marine invertebrates. Ecology 65:423-437

Keough MJ, Raimondi PT (1995) Responses of settling invertebrate larvae to bioorganic films: effects of different types of films. J Exp Mar Biol Ecol 185:235-253

Keough MJ, Raimondi PT (1996) Responses of settling invertebrate larvae to biofilms: effects of large scale variation in films. J Exp Mar Biol Ecol 207:59-78

Kimball KD, Levin SA (1985) Limitations of laboratory bioassays: The need for more ecosystem level testing. BioScience 35:165-171

Lenth R (1997) PiFace. University of Iowa

Luoma SN (1995) Prediction of metal toxicity in nature from bioassays: limitations and research needs. In: Tessier A, Turner DR (eds) Metal speciation and bioavailability in aquatic systems. John Wiley \& Sons, Chichester, p 609-646

Luoma SN, Phillips DJH (1988) Distribution, variability, and impacts of trace elements in San Francisco Bay. Mar Pollut Bull 19:413-425

Lynch W (1961) Extrinsic factors influencing metamorphosis in bryozoan and ascidian larvae. Am Zool 1:59-66

Menge BA (1995) Indirect effects in marine rocky intertidal interaction webs: patterns and importance. Ecol Monogr 65:21-74

Nandakumar K, Tanaka M, Kikuchi T (1993) Interspecific competition among fouling organisms in Tomioko Bay, Japan. Mar Ecol Prog Ser 94:43-50

Osman R (1977) The establishment and development of a marine epifaunal community. Ecol Monogr 47:37-63

Paine RT (1966) Food web complexity and species diversity. Am Nat 100:65-75

Paine RT (1974) Intertidal community structure: experimental studies on the relationship between a dominant competitor and its principal predator. Oecologia 15:93-120

Paulson AJ, Curl HCJ, Feely RA (1989) Estimates of trace metal inputs from non-point sources discharged into estuaries. Mar Pollut Bull 20:549-555

Petraitis PS (1990) Direct and indirect effects of predation, herbivory and surface rugosity on mussel recruitment. Oecologia 83:405-413

Petraitis PS, Latham RE, Niesenbaum RA (1989) The maintenance of species diversity by disturbance. Q Rev Biol 64: $393-418$

Pitt RE (1995) Effects of urban runoff on aquatic biota. In: Hoffman DJ, Rattner BA, Burton GAJ, Cairns JJ (eds) Handbook of ecotoxicology. Lewis Publishers, Boca Raton, FL, p 609-630

Quinn GP, Keough MJ (2002) Experimental design and data analysis for biologists. Cambridge University Press, Cambridge

Raimondi PT (1990) Patterns, mechanisms, consequences of variability in settlement and recruitment of an intertidal barnacle. Ecol Monogr 60:283-309

Reed DC, Raimondi PT, Carr MH, Goldwasser L (2000) The role of dispersal and disturbance in determining spatial heterogeneity in sedentary organisms. Ecology 81:2011-2026

Russ GW (1980) Effects of predation by fishes, competition, and structural complexity of the substratum on the establishment of a marine epifaunal community. J Exp Mar Biol Ecol 42:55-69

Rygg B (1985) Distribution of species along pollution induced diversity gradients in benthic communities in Norwegian Fjords. Mar Pollut Bull 16:469-474

Schmitt RJ (1987) Indirect interactions between prey: apparent competition, predator aggregation, and habitat segregation. Ecology 68:1887-1897

Stauber JL, Benning RJ, Hales LT, Eriksen R, Nowak B (2000) Copper bioavailability and amelioration of toxicity in Macquarie Harbour, Tasmania, Australia. Mar Freshw Res 51: $1-10$

Stephenson MD, Leonard GH (1994) Evidence for the decline of silver and lead and the increase of copper from 1977 to 1990 in the coastal marine waters of California. Mar Pollut Bull 28:148-153

Sutherland JP (1974) Multiple stable points in natural communities. Am Nat 108:859-873

Sutherland JP, Karlson RH (1977) Development and stability of the fouling community at Beaufort, North Carolina. Ecol Monogr 47:425-446

Tanner JE, Hughes T, Connell JH (1994) Species coexistence, keystone species, and succession: a sensitivity analysis. Ecology 75:2204-2219

Tilman D (1990) Constraints and tradeoffs: toward a predictive theory of competition and succession. Oikos 58:3-15

Tilman D (1994) Competition and biodiversity in spatially structured habitats. Ecology 75:2-16

Unabia C, Hadfield MG (1999) Role of bacteria in larval settlement and metamorphosis of the polychaete Hydroides elegans. Mar Biol 133:55-64 
Wiens JA, Parker K (1995) Analyzing the effects of accidental environmental impacts: approaches and assumptions. Ecol Appl 5:1069-1083

Wisely B (1963) Effects of antifouling paints on settling larvae of the bryozoan Bugula neritina L. Aust J Mar Freshw Res 18:63-72

Editorial responsibility: Otto Kinne (Editor), Oldendorf/Luhe, Germany
Wootton JT (1992) Indirect effects, prey susceptibility, and habitat selection: impacts of birds on limpets and algae. Ecology 73:981-991

Wootton JT (1994) Predicting direct and indirect effects: an integrated approach to using experiments and path analysis. Ecology 75:151-165

Submitted: September 26, 2002; Accepted: December 10, 2002 Proofs received from author(s): March 24, 2003 